\title{
Vibriosis and Aeromonas infection in shrimp: Isolation, sequencing, and control
}

\author{
Hanaa Mohamed Fadel ${ }^{1}$ and Maather El-Lamie M.M. ${ }^{2}$
}

1. Department of Animal Hygiene and Zoonoses, Faculty of Veterinary Medicine, Suez Canal University, Ismailia, Egypt; 2. Department of Fish Diseases and Management, Faculty of Veterinary Medicine, Suez Canal University, Ismailia, Egypt. Corresponding author: Hanaa Mohamed Fadel, e-mail: hanaamohamedfadel@ymail.com

Co-author: MEMM: maather76@yahoo.com

Received: 04-01-2019, Accepted: 18-03-2019, Published online: 14-05-2019

doi: 10.14202/IJOH.2019.38-48 How to cite this article: Fadel HM, El-Lamie MMM. Vibriosis and Aeromonas infection in shrimp: Isolation, sequencing, and control. Int J One Health 2019;5:38-48.

\begin{abstract}
Background and Aim: Shrimp is one of the most commonly consumed types of seafood. It is a very nutritious healthy food. Shrimp is low in calories and rich in protein and healthy fats. It also contains a treasure trove of vitamins and minerals. On the negative side, it may be affected by many bacterial diseases which affect its health. Furthermore, it may be incriminated as a vector of foodborne illnesses that range from mild gastrointestinal upset to life-threatening diseases. This study was designed to assess the clinical picture and zoonotic importance of vibriosis and Aeromonas infection in live shrimp and to study the antibacterial effect of citric acid (lemon juice) and acetic acid (vinegar) on these pathogens.

Materials and Methods: A total of 170 live shrimp (Metapenaeus monoceros) samples were collected from Suez City, Egypt. The samples were examined clinically, and then, they were enriched into alkaline peptone water and cultivated on thiosulfate-citrate-bile salts-sucrose agar and ampicillin MacConkey agar for the isolation of Vibrio and Aeromonas species, respectively. The recovered isolates were confirmed biochemically and genotypically using duplex polymerase chain reaction (PCR) and sequencing. The germicidal effects of vinegar and lemon on artificially contaminated shrimp samples with Aeromonas hydrophila and Vibrio parahaemolyticus at different times $(0.25,1,1.5$, and $24 \mathrm{~h})$ and temperatures $\left(5^{\circ}\right.$ and $30^{\circ} \mathrm{C}$ ) were studied.

Results: The results revealed that some of the infected shrimp were hypoxic, lethargic with abnormal swimming behavior. In most cases, body appendages, telsons, uropods, and gills took black coloration. In addition, the hepatopancreas appeared soft, swollen, and congested. The prevalence rates of vibriosis in each of the musculature and hepatopancreas were $4.7 \%$, while the prevalence rates of Aeromonas infection in the musculature and hepatopancreas were $11.8 \%$ and $11.2 \%$, respectively. Duplex PCR showed that Aeromonas isolates gave double bands: $237 \mathrm{bp}$ specific for gcat and $500 \mathrm{bp}$ specific for 16S rRNA, while Vibrio spp. and Plesiomonas shigelloides isolates gave single band at $500 \mathrm{bp}$. The effect of organic acid treatment showed that acetic acid (vinegar 5\%) had increasing reduction rates that reached its maximum level after $24 \mathrm{~h}$; where it caused (100\% inhibition) for A. hydrophila at both temperatures and (33.63\% and 60\% inhibition) for V. parahaemolyticus at refrigerator and room temperatures, respectively. Moreover, acetic acid was more effective at room temperature than at refrigerator temperature. Concerning the effect of lemon juice (citric acid), it was more effective than acetic acid at short marination $(0.25$ and $1 \mathrm{~h}$ ) at both temperatures for the two pathogens. Moreover, lemon was more effective at refrigerator temperature than at room temperature at the same aforementioned time. The difference between the reduction effects of the two acids on both pathogens was statistically significant $(\mathrm{p}<0.0001)$.
\end{abstract}

Conclusion: Overall, the examined shrimp samples were found to be vectors for Vibrio and Aeromonas spp. Application of hygienic measures during handling and cooking of shrimp should be esteemed. The organic acid treatment trial showed that vinegar and lemon juice can be used as a safe and economic method to limit the microbial contamination in seafood.

Keywords: Shrimp, vibriosis, Aeromonas infection, sequencing, decontamination, citric acid, acetic acid

\section{Introduction}

Shrimp is highly valued as a source of animal protein [1]. From another side, seafoods are considered as vectors in human outbreaks [2]. Many bacteria incriminated to cause diseases for shrimp are normal inhabitants for marine environments and are considered as opportunistic pathogens [3] when natural

Copyright: Fadel and El-Lamie. This article is an open access article distributed under the terms of the Creative Commons Attribution 4.0 International License (http://creativecommons.org/ licenses/ by/4.0/), which permits unrestricted use, distribution, and reproduction in any medium, provided you give appropriate credit to the original author(s) and the source, provide a link to the Creative Commons license, and indicate if changes were made. The Creative Commons Public Domain Dedication waiver (http:// creativecommons.org/ publicdomain/zero/1.0/) applies to the data made available in this article, unless otherwise stated. defense mechanisms are suppressed [4]. The most important bacterial pathogens which cause diseases in shrimp are Vibrio spp., Pseudomonas spp., and Aeromonas spp. [5].

Vibrio spp. are the most isolated bacteria from diseased shrimps [6]. They are Gram-negative bacteria that inhabit estuarine and coastal waters [7]. Twelve species of the genus Vibrio are pathogenic to humans. The most encountered species in seafood-borne infection are Vibrio Parahaemolyticus, Vibrio vulnificus, and Vibrio alginolyticus. The infection is transmitted by ingestion of raw seafood or through wound infection (during swimming in contaminated water or handling infected seafood). The recorded illness includes (1) infection of the eyes, ears, or 
open wounds, (2) primary septicemia with symptoms including fever, and blistering skin lesions that lead to extensive necrosis and necessitate amputation of limbs, and (3) gastroenteritis [8].

Vibriosis in shrimp appears as a number of syndromes (oral and enteric vibriosis, appendage and cuticular vibriosis, localized vibriosis of wounds, shell disease, systemic vibriosis, and septic hepatopancreatitis) [9]. Vibrio harveyi luminescent strains cause about 80-100\% mortality in Penaeus monodon hatcheries [10] and Fenneropenaeus indicus culture [11]. Furthermore, Li et al. [12] recorded that $V$. parahaemolyticus toxic strains which cause acute hepatopancreatic necrosis will severely damage the global shrimp industry, while $V$. alginolyticus was demonstrated to be the most common organism isolated from the diseased shrimps with signs of septicemia [13].

Aeromonas species are Gram-negative bacteria that are ubiquitous in aquatic environments. The genus Aeromonas includes the mesophilic aeromonads: Aeromonas hydrophila, Aeromonas caviae, Aeromonas sobria, Aeromonas veronii, and Aeromonas schuberti. They are renowned as emerging enteric pathogens of public health concern. Mesophilic aeromonads are etiologic agents of a broad spectrum of diseases in man such as gastroenteritis, soft tissue, muscle infections, septicemia, and skin disease $[8,14]$.

They were isolated from tissues and hemolymph of cultured penaeid shrimp. They cause shell disease with melanization of cuticle, gills, body, and appendages. Moreover, septicemia of juvenile and adult cultured penaeid shrimp and brown spot disease were recorded [3].

By increasing of consumers' needs for safe, natural, and non-toxic preservatives that can be used at household level, organic acids have GRAS (Generally Recognized as Safe) status, and hence, they are used extensively as food preservatives and additives for perishable food items [15]. These compounds are composed of saturated straight-chained monocarboxylic acids and their derivatives [16]. The antimicrobial properties of organic acids are attributed to their low pH. It is established that undissociated forms (uncharged or protonated forms) of organic acids can penetrate the lipid membrane of the bacterial cell, while the dissociated (non-protonated or charged forms) forms cannot. Once the uncharged acid enters the cytoplasm, it dissociates into anions and protons. The bacterial cell has to consume more energy in the form of adenosine triphosphate (ATP) to keep its neutrality and hence depletion of cellular energy and hindering of cell growth occur [17].

The objectives of this study were to record the clinical picture of vibriosis and Aeromonas infection in naturally infected shrimp, isolation and identification of the causative organisms by conventional culture method, confirmation of the isolates using duplex polymerase chain reaction (PCR) reaction, sequencing, and finally control of shrimp contamination using acetic acid (vinegar) and citric acid (lemon juice).

\section{Materials and Methods}

Ethical approval

The definition of animal (for experimental use) by any of the international consortia or Animal Research Act (ARA) does not include invertebrates (excluding Cephalopods) as test animals and hence does not require ethical committee approval [18]. However, we humanely handled the shrimps at the lab, removed them from the transporting seawater and they were left to die before processing of samples.

\section{Sampling and clinical picture [19]}

One hundred and seventy live shrimp samples (Metapenaeus monoceros) were purchased from fishermen in Suez city, Egypt, during the period from June to September 2016. The samples were placed in sterile seawater in an ice box immediately after capturing and were transported to the Laboratory of Zoonoses, Faculty of Veterinary Medicine, Suez Canal University, Ismailia, Egypt. Their body weights ranged from 16 to $18 \mathrm{~g}$. The clinical picture of naturally infected shrimps was designated as live, moribund, and freshly dead ones.

\section{Preparation of samples [20] Hepatopancreas}

The carapace was lifted using sterile forceps, and from inside the hepatopancreas, two inoculums were taken using sterile cotton swabs and inoculated into two tubes containing $9 \mathrm{ml}$ of sterile alkaline peptone water (APW, pH: 8, CM1028 Oxoid, UK) and APW (pH: 8) supplemented with $3 \% \mathrm{NaCl}$ for the isolation of Aeromonas and Vibrio spp., respectively.

\section{Musculature}

The surface was hot seared using hot scissors, and each shrimp sample was aseptically divided into two equal parts (5 g each); one part was stomached with $45 \mathrm{ml}$ of APW in sterile polyethylene sacs, and the other part was stomached with $45 \mathrm{ml}$ of APW supplemented with $3 \% \mathrm{NaCl}$ for the isolation of Aeromonas and Vibrio spp., respectively.

Isolation and identification of Aeromonas spp. [21,22]

The APW tubes were incubated at $35^{\circ} \mathrm{C}$ for $24 \mathrm{~h}$. A loopful of the incubated broth was streaked onto well-dried MacConkey-ampicillin agar $(20 \mu \mathrm{g} /$ $\mathrm{ml}$, Lab M, UK) plates to be incubated at $35^{\circ} \mathrm{C}$ for 48 h. Colorless colonies were selected, purified, and identified.

\section{Isolation and identification of Vibrio spp. [23]}

The APW tubes supplemented with $3 \% \mathrm{NaCl}$ were incubated at $35^{\circ} \mathrm{C}$ for $24 \mathrm{~h}$. A loopful of the incubated broth was streaked onto well-dried thiosulfate-citrate-bile salts-sucrose agar (TCBS, Hardy Diagnostics, USA) plates to be incubated at $35^{\circ} \mathrm{C}$ for $72-96 \mathrm{~h}$. Yellow, blue, or green colonies were picked up, purified, and identified. 


\section{Maintenance of isolates}

Isolates were incubated in tryptic soy broth (TSB, Becton Dickinson, GmbH, Germany). $500 \mu \mathrm{l}$ of the overnight culture was added to $500 \mu \mathrm{l}$ of $50 \%$ glycerol $(100 \%$ glycerol diluted in sterile distilled $\mathrm{H} 2 \mathrm{O}$ ) in a $2 \mathrm{ml}$ screw-top tube and was gently mixed and kept frozen at $-20^{\circ} \mathrm{C}$.

\section{PCR confirmation of isolates}

DNA was extracted from isolates by boiling centrifugation method [24]. Duplex PCR technique that allowed detection of Vibrio and Aeromonas spp. was performed following the technique of MendesMarques et al. [25]. Primers were designed by Bio Basic Inc., Canada. Briefly, the reaction was carried out in $25 \mu \mathrm{l}$ reaction that consisted of $5 \mu \mathrm{l}$ of DNA, $1.5 \mu \mathrm{l}$ of gcat-f:5'-ctcctggaatcccaagtatcag-3' and 1.5 $\mu \mathrm{l}$ of gcat-r: 5'-ggcaggttgaacagcagtatct-3', $1.5 \mu \mathrm{l}$ of 16S-f: 5'-acgcaggcggttggataagt-3' and $1.5 \mu \mathrm{l}$ of $16 \mathrm{~S}$ r: 5'-ggcaacaaaggacaggggt-3', $12.5 \mu \mathrm{l}$ of PCR Master Mix (GeneDirex, USA), and $1.5 \mu \mathrm{l}$ of sterile milliQ water. The PCR reaction was run in a thermal cycler (Techne, England) and programmed for 35 cycles of $1 \mathrm{~min}$ at $94^{\circ} \mathrm{C}, 1 \mathrm{~min}$ at $54^{\circ} \mathrm{C}, 1 \mathrm{~min}$ at $72^{\circ} \mathrm{C}$, and a final 5 min extension at $72^{\circ} \mathrm{C}$. Five $\mu 1$ of PCR product was electrophoresed in $1.5 \%$ agarose containing ethidium bromide $(0.1-0.5 \mu \mathrm{g} / \mathrm{ml})$ along with $100 \mathrm{bp}$ DNA ladder for $1 \mathrm{~h}$. The PCR product was viewed and recorded using the SynGene Gel Documentation System. Aeromonas spp. give double bands: $\sim 237 \mathrm{bp}$ specific for gcat and $\sim 500 \mathrm{bp}$ specific for 16S rRNA, while Vibrio spp. give single band at $\sim 500 \mathrm{bp}$.

\section{Sequencing of selected isolates [26]}

Selected isolates were sequenced; the bacterial 16S rRNA gene was amplified using the bacteria-specific primers 27F-P (5'GAGTTTGATCCTGGCTCAG-3') together with the universal primer 1492R-P (5'- GGTTACCTTGTTACGACTT-3'). PCR was performed on a GeneAmp PCR system 9600 (Applied Biosystems, Thermo Fisher Scientific, USA), and the total reaction volume was $50 \mu \mathrm{l}: 25 \mu \mathrm{l}$ AmpliTaq Gold (Applied Biosystems), $2 \mu \mathrm{l}$ each (10 pM) of forward and reverse primers, $19 \mu \mathrm{l}$ sterile Milli-Q water, and $2 \mu \mathrm{l}$ of DNA template. The PCR programming included initial denaturation at $95^{\circ} \mathrm{C}$ for $5 \mathrm{~min}$, followed by 35 cycles of denaturation at $95^{\circ} \mathrm{C}$ for $30 \mathrm{~s}$, annealing at $50^{\circ} \mathrm{C}$ for $30 \mathrm{~s}$, extension at $72^{\circ} \mathrm{C}$ for $1.5 \mathrm{~min}$, final extension at $72^{\circ} \mathrm{C}$ for $5 \mathrm{~min}$, and holding at $4^{\circ} \mathrm{C}$. PCR products were visualized through electrophoresis on a $1 \%$ agarose gel with ethidium bromide. Clones (ca. 1500 bp) were sequenced bidirectionally using the forward and reverse primers (Solgent Company Ltd., Korea). Sequence files were scored and compared to the GenBank nucleotide database using the Basic Local Alignment Search Tool.

\section{Decontamination of shrimp samples $[27,28]$}

The antibacterial effects of two organic acids (acetic and citric) against A. hydrophila and V. parahaemolyticus were studied.

\section{Preparation of inoculating bacteria}

TSB was inoculated with $A$. hydrophila colonies and incubated at $35^{\circ} \mathrm{C}$ for $24 \mathrm{~h}$. Ten-fold serial dilutions were prepared. $100 \mu$ of each dilution was spread evenly onto the surface of MacConkey agar plates and was incubated at $35^{\circ} \mathrm{C}$ for $24 \mathrm{~h}$. Plates showing 30-300 colonies were counted. An initial count of $7.5 \log _{10} \mathrm{cfu} / \mathrm{ml}$ was selected.

$V$. parahaemolyticus strain was grown into TSB supplemented with $3 \% \mathrm{NaCl}$ at $35^{\circ} \mathrm{C}$ for $24 \mathrm{~h}$. Tenfold serial dilutions were prepared. One hundred $\mu 1$ of each dilution was spread evenly onto surface of TCBS agar plates and was incubated at $35^{\circ} \mathrm{C}$ for $24 \mathrm{~h}$. An initial count of $8 \log _{10} \mathrm{cfu} / \mathrm{ml}$ was selected.

\section{Preparation of organic acid solutions}

About $1 \mathrm{~L}$ of each of commercial vinegar $(5 \%)$ and freshly squeezed lemon fruit juice (Citrus aurantiifolia) was used to test the antibacterial activity of acetic and citric acids against Aeromonas and Vibrio. One lemon yields about $45 \mathrm{ml}$ of juice. The juice of the lemon contains about 5-6\% citric acid, with a $\mathrm{pH}$ of around 2.2.

\section{Inoculating shrimp samples with the bacterial strains}

The inoculation was done separately for each pathogen.

Freshly caught shrimp samples were rinsed with sterile saline solution and allowed to drip on sterile metal mesh. Then, they were disinfected by dipping in ethyl alcohol (70\%) for $5 \mathrm{~min}$. After that, they were allowed to drip on sterile metal mesh in laminar flow hood. After complete dryness, shrimp samples were dipped for $45 \mathrm{~min}$ in $1 \mathrm{~L}$ of the bacterial suspension (with 10 times clockwise and counterclockwise shaking every $5 \mathrm{~min}$ for the whole period) to allow adhesion of Aeromonas to the samples.

The initial bacterial load was determined by ten-fold serial dilutions in sterile saline and $100 \mu \mathrm{l}$ from each dilution was spread over MacConkey agar plates and incubated at $35^{\circ} \mathrm{C}$ for $24 \mathrm{~h}$. The experiment was run in triplicates at refrigerator temperature $\left(5 \pm 2^{\circ} \mathrm{C}\right)$ and at room temperature $\left(30 \pm 2^{\circ} \mathrm{C}\right)$ according to Diagram- $1 \mathrm{a}$ and $\mathrm{b}$.

The control consisted of inoculated shrimp samples dipped in sterile saline solution.

After each specified time, treated shrimp samples were picked up using sterile forceps and allowed to dry on a sterile tissue, $10 \mathrm{~g}$ of the musculature of treated shrimp samples were aseptically weighed into $90 \mathrm{ml}$ of sterile saline, homogenized in a stomacher, and ten-fold serial dilutions in sterile saline were carried out as aforementioned. The plates showing 30-300 colonies were counted. The $\log _{10} \mathrm{cfu} / \mathrm{g}$ was calculated.

For Vibrio, the same procedures were used except for using $3 \% \mathrm{NaCl}$ for serial dilution and as a control and using TCBS as spreading medium. The plates showing 30-300 colonies were counted. The $\log _{10} \mathrm{cfu} / \mathrm{g}$ was calculated. 


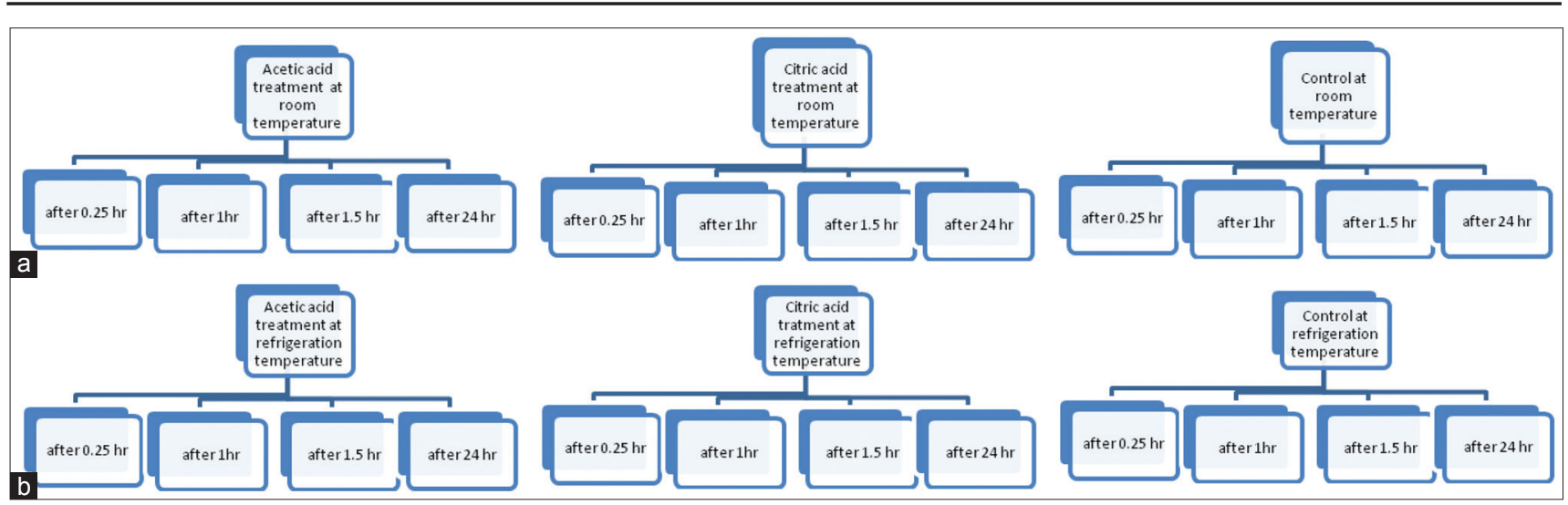

Diagram-1: Experiment (a): At room temperature and (b): At refrigerator temperature.

\section{Statistical analysis}

Comparison of the isolation percentages of Aeromonas and Vibrio was done using Fisher's exact test (SPSS version 20). Comparison of means of treatments and control was done using Kruskal-Wallis test (non-parametric ANOVA). p-value was set at $\leq 0.05$ (SPSS version 20).

$\log _{10}$ reduction and reduction percentages were calculated using Excel software [29].

$$
\log _{10} \text { reduction }=(A)-(B) \text {. }
$$

Where $A=\log _{10}$ number of viable microorganisms before treatment.

$\mathrm{B}=\log _{10}$ number of viable microorganisms after treatment.

Log reduction $\%=\frac{(\mathrm{A}-\mathrm{B})}{\mathrm{A}} \times 100$

If the number is negative, this indicates a $\log _{10}$ increase in number and percentage.

\section{Results}

\section{Clinical picture}

Some of the naturally infected shrimp (M. monoceros) appeared hypoxic and lethargic with abnormal swimming behavior near tank edges and at the water surface. Gill covers were somewhat raised up. Some cases showed white spots on the carapaces, and others had black patches on the cuticle (Figure-1a). In most cases, body appendages, telsons, uropods, and gills took black coloration with deformity of pleopods (Figure-1a and b). Reddish coloration of pereopods and pleopods was recorded in a few cases. Hepatopancreas appeared soft, swollen, and congested (Figure-1c).

\section{Prevalence of vibriosis and Aeromonas infections}

Among the 170 examined samples, the total prevalence of vibriosis was $7 / 170,4.12 \%$. On the other hand, $16(9.41 \%)$ of 170 tested shrimp samples were infected with Aeromonas (data were not shown in tables). Hepatopancreas and musculature showed the same prevalence of vibriosis $(4.7 \%)$. For Aeromonas, nearly similar prevalences in hepatopancreas (11.2\%) and musculature (11.8\%) were recorded. The difference between the total prevalence

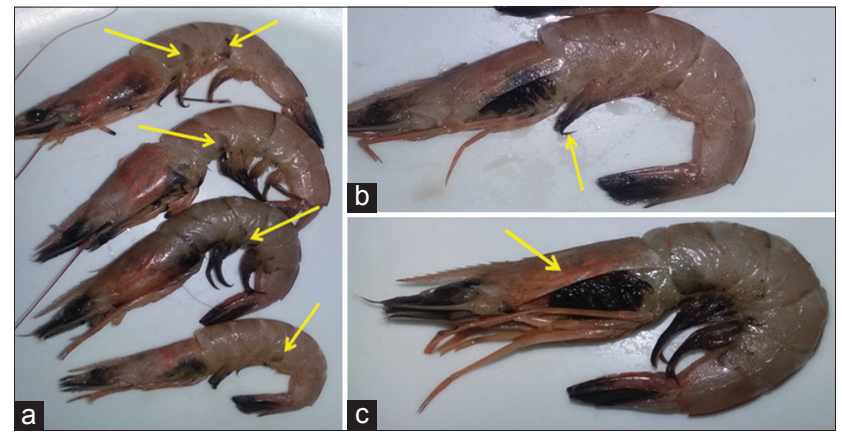

Figure-1: Infected Metapenaeus monoceros showing, (a): Black patches on cuticle (arrows) and black coloration of body appendages, telsons, and uropods. (b): Black coloration of gills and pleopods (swimmers) deformity. (c): Congested hepatopancreas underneath the carapace (arrow).

rates of Aeromonas infection and vibriosis was not considered significant. Odds ratio $=2.419(95 \%$ confidence interval: 0.9687-6.042), $\mathrm{p}=0.0821$ (Table-1).

Biochemically, V. parahaemolyticus, $V$. vulnificus, V. alginolyticus, A. hydrophila, and A. sobria were identified.

On sequencing of some biochemically confirmed isolates and others having doubtful results, A. hydrophila, A. sobria, A. veronii, Plesiomonas shigelloides, Pseudomonas putida, and Pseudomonas fluorescens were confirmed. Concerning Vibrio isolates, they gave conflicting sequence result and could not be identified.

Duplex PCR showed that Aeromonas spp. gave double bands: $237 \mathrm{bp}$ specific for gcat and $500 \mathrm{bp}$ specific for $16 \mathrm{~S}$ rRNA, while Vibrio and $P$. shigelloides gave single band at 500 bp (Figure-2).

Effect of decontamination using organic acids on A. hydrophila and $\boldsymbol{V}$. parahaemolyticus counts

Table-2 and Figure-3 depict the effect of acetic acid treatment on $A$. hydrophila count at room temperature for $0.25,1,1.5$, and $24 \mathrm{~h}$. The $\log$ reduction values were $1.28,1.39,2.03$, and 7.5 and $\log$ reduction percentages were 17.07, 18.5, 27.07, and 100, while, for $V$. parahaemolyticus, the log reductions were 0.43 , $0.52,1.6$, and 4.8 and the $\log$ reduction percentages 
Table-1: Prevalence of vibriosis and Aeromonas infection in the examined shrimp (Metapenaeus monoceros) samples.

\begin{tabular}{|c|c|c|c|c|}
\hline \multirow[t]{3}{*}{ Number of examined samples } & \multicolumn{2}{|c|}{ Vibriosis } & \multicolumn{2}{|c|}{ Aeromonas infection } \\
\hline & Hepatopancreas & Musculature & Hepatopancreas & Musculature \\
\hline & n (\%) & n (\%) & n (\%) & n (\%) \\
\hline 170 & $8(4.7)$ & $8(4.7)$ & $19(11.2)$ & $20(11.8)$ \\
\hline
\end{tabular}

The odds ratio $=2.419(95 \% \mathrm{CI}: 0.9687-6.042), \mathrm{p}=0.0821 . \mathrm{CI}=$ Confidence interval

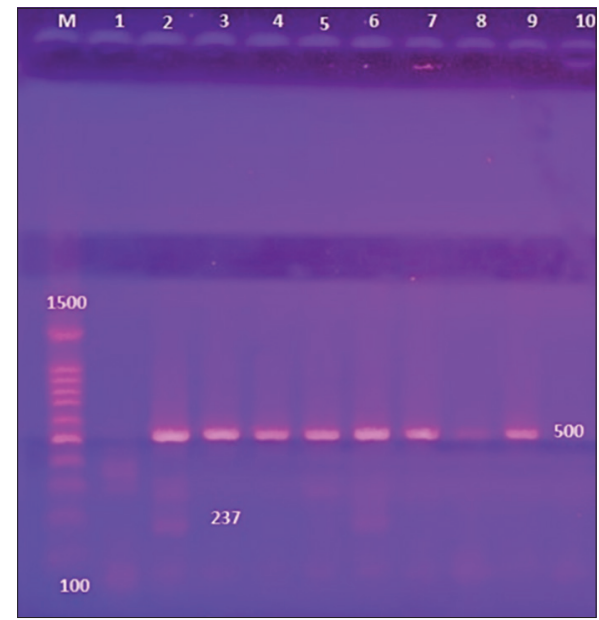

Figure-2: Amplification of gcat and $16 \mathrm{~S}$ rRNA genes. Lane M: 100 bp DNA ladder. Lane 1: negative control. Lanes 2 and 6: Aeromonas hydrophila and Aeromonas veronii gave double bands: 237 bp specific for gcat and 500 bp specific for 16S rRNA. Lanes 3, 4, 8, and 9: Vibrio gave $500 \mathrm{bp}$ specific for $16 \mathrm{~S}$ rRNA. Lanes 5 and 7: Plesiomonas shigelloides gave 500 bp specific for 16S rRNA.

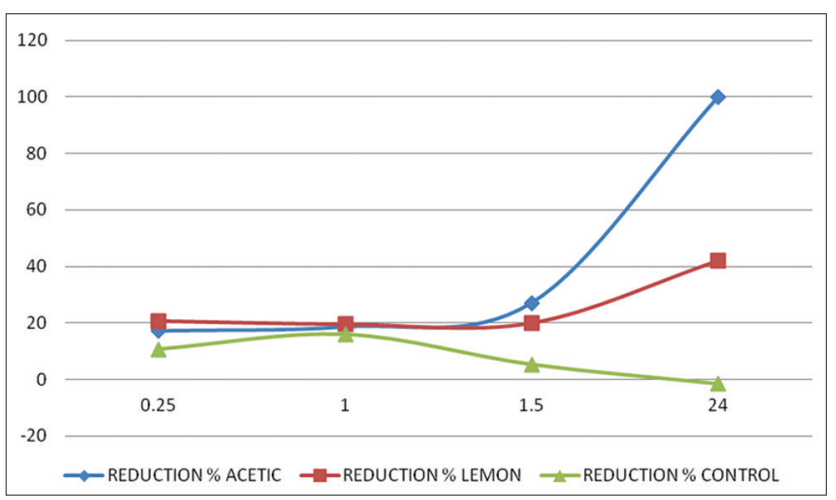

Figure-3: Reduction percentages of Aeromonas hydrophila count at room temperature using different treatments.

were $5.38,6.5,20$, and 60 , respectively (Table- 3 and Figure-4).

In the acetic acid treatment experiment at refrigerator temperature with A. hydrophila for 0.25 , $1,1.5$, and $24 \mathrm{~h}$, the $\log$ reductions were $1.13,1.39$, 1.9 , and 7.5 and the $\log$ reduction percentages were $15.07,18.53,25.33$, and 100, respectively (Table-2 and Figure-5), while the log reductions for $V$. parahaemolyticus were $0.35,0.42,1.46$, and 2.69 and the reduction percentages were $4.38,5.25,18.25$, and 33.63, respectively (Table-3 and Figure-6).

With respect to the effect of citric acid treatment on the count of $A$. hydrophila at room temperature for $0.25,1,1.5$, and $24 \mathrm{~h}$, the $\log$ reductions reached 1.55 ,

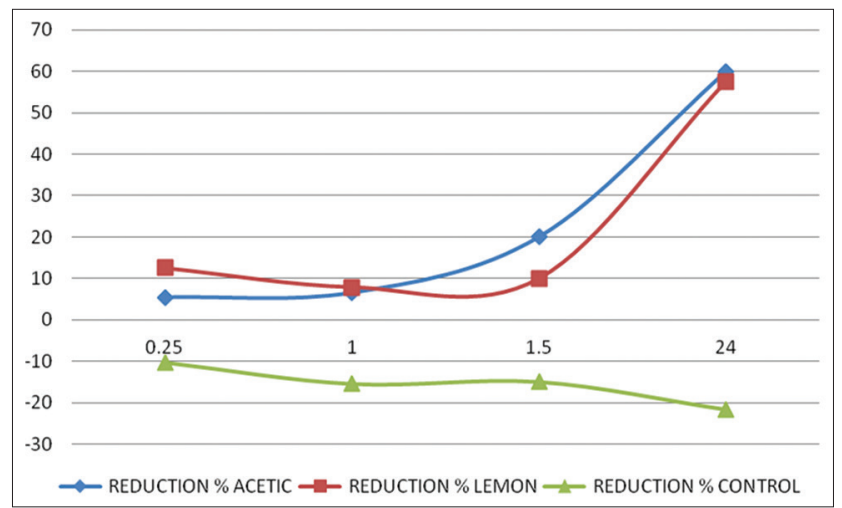

Figure-4: Reduction percentages of Vibrio parahaemolyticus count at room temperature using different treatments.

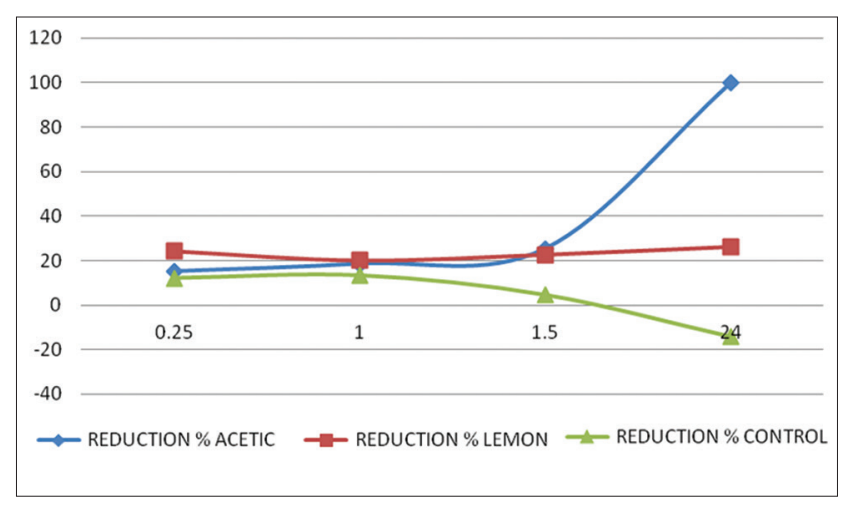

Figure-5: Reduction percentages of Aeromonas hydrophila count at refrigerator temperature using different treatments.

$1.47,1.53$, and 3.15 and the reduction percentages were $20.67,19.61,20.4$, and 42, respectively (Table-2 and Figure-3), while, for Vibrio, the log reductions were 1, $0.44,0.8$, and 4.61 and the reduction percentages were 12.5, 5.5, 10, and 57.63 (Table-3 and Figure-4).

In the citric acid treatment experiment at refrigerator temperature with Aeromonas for 0.25, 1, 1.5, and $24 \mathrm{~h}$, the $\log$ reductions were $1.82,1.5,1.7$, and 1.97 and the reduction percentages were $24.27,20$, 22.67, and 26.27 (Table-2 and Figure-5), while, for Vibrio, the $\log$ reductions were $1.06,0.63,0.53$, and 1.99 and the reduction percentages were $13.25,7.9$, 6.63 , and 24.88, respectively (Table-3 and Figure-6).

Overall, citric acid was more effective at refrigerator temperature than citric acid at room temperature at 0.25 and $1 \mathrm{~h}$. Furthermore, citric acid was more effective than acetic acid at short marination $(0.25$ and $1 \mathrm{~h})$ at both temperatures for the two pathogens. After that time, acetic acid showed superiority. 


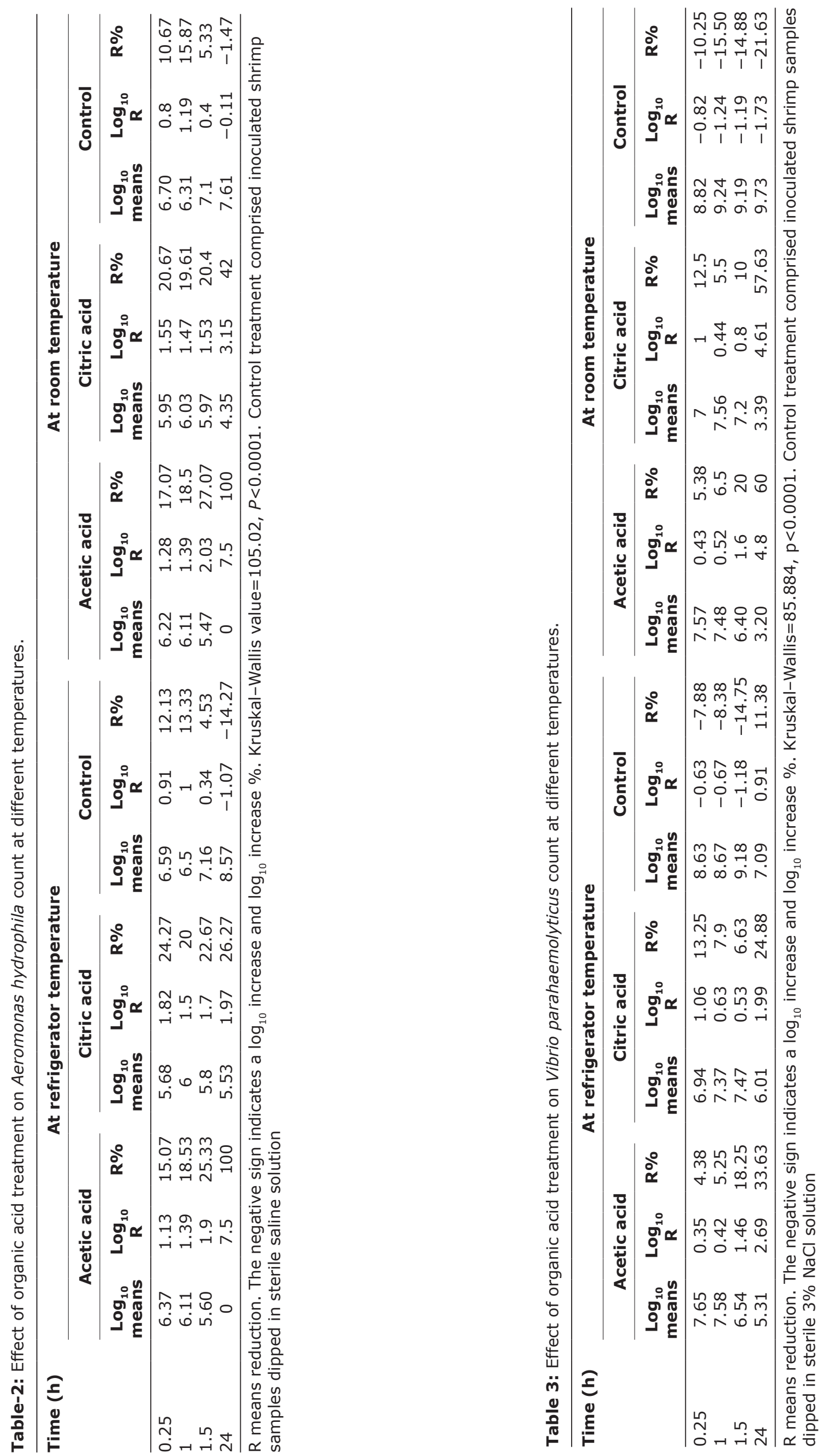




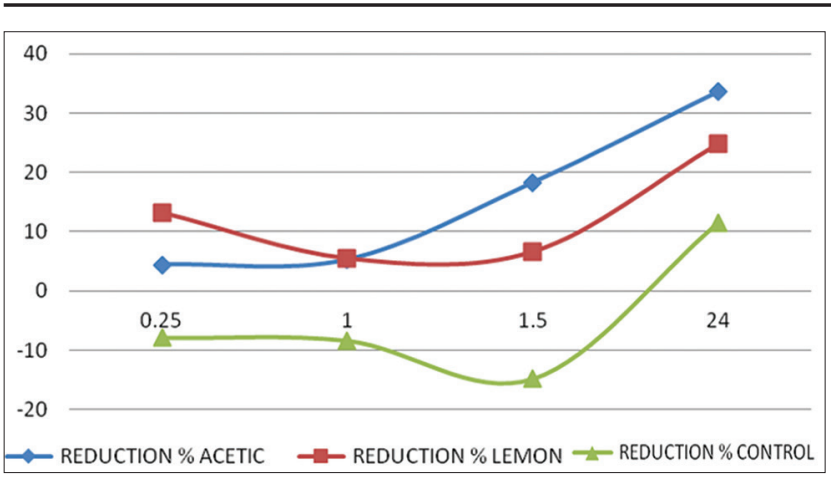

Figure-6: Reduction percentages of Vibrio parahaemolyticus count at refrigerator temperature using different treatments.

While for acetic acid, it showed an ascending increase in the reduction percentages to reach $100 \%$ reduction for Aeromonas at $24 \mathrm{~h}$ at both temperatures and $(33.63 \%$ and $60 \%)$ reduction for $V$. parahaemolyticus at refrigerator and room temperatures, respectively. Overall, the reduction effect using acetic acid was more effective at room temperature than that at refrigerator temperature for both microorganisms.

The difference between the reduction effects of the two acids on both pathogens was significant. Kruskal-Wallis value $=105.02,85.88, \mathrm{p}<0.0001$ for $A$. hydrophila and $V$. parahaemolyticus, respectively.

\section{Discussion}

\section{Clinical picture of infected shrimp}

In the present study, the infected $M$. monoceros appeared hypoxic and lethargic with abnormal swimming behavior near tank edges and at water surface. These results were similar to what was recorded by Alavandi et al. [5] and Biju and Gunalan [30] due to vibriosis and Cheng et al. [31] due to $A$. veronii infection in the ornamental shrimp (Caridina cf. babaulti). This may be due to gills' infection. As gills are covered by thin exoskeleton, so they are easily penetrated by bacterial pathogens [32]. Some cases showed white spots on the carapace as what was recorded by Ali and Abo-Esa [33]. Furthermore, black patches were seen on the cuticle. Body appendages, telsons, uropods, and gills took black coloration. These results were recorded due to vibriosis and Aeromonas spp. infection [5], while Zaki et al. [11] recorded tissue and appendages necrosis in $F$. indicus culture infected with vibriosis. These may be due to the distribution of melanophores in the affected area and that makes a black ring which separates healthy tissue from the affected one [34]. The most important bacterial pathogens which cause shell disease in shrimp are Vibrio spp., Pseudomonas spp., and Aeromonas spp. [5]. Shrimp with vibriosis has body discoloration. Reddish coloration was recorded on pereiopods and pleopods as a result of expansion of chromatophores [5]. A special group of Vibrio has a luminescence character as heavily infected shrimp appears "glow-in-the-dark" $[10,35]$. Hepatopancreas is the target organ of most bacterial infections of shrimp
[35]. In the current study, hepatopancreas of the infected shrimp appeared to be soft, swollen, and congested, while Ali and Abo-Esa [33] recorded paleness and hemorrhagic patches on it in Penaeus semisulcatus affected by $V$. alginolyticus. It appeared atrophied and pale due to acute hepatopancreatic necrosis disease caused by $V$. parahaemolyticus strains [12]. Furthermore, Aly and El-Attar [36] recorded the same signs and lesions due to P. fluorescens in freshwater shrimp in Egypt.

\section{Prevalence and public health significance of vibriosis and Aeromonas infection in shrimp}

Vibrio spp. has been encountered in seafood-borne infection which is transmitted by ingestion or handling of raw seafood. The disease varied from gastroenteritis to septicemic life-threatening illness [8]. Aeromonas species are emerging enteric pathogens of public health concern. They inhabit the aquatic environment. They can cause a broad spectrum of diseases in man such as gastroenteritis, wound infection, septicemia, and skin disease $[8,14]$.

The available literature included various levels of Vibrio and Aeromonas infection in shrimp. El-Hadi et al. [37] detected Vibrio spp. in $4.6 \%$ of examined shellfish in Malaysia. Eight Vibrio spp. were recovered from shrimp that included Vibrio cholerae, V. parahaemolyticus, V. vulnificus, V. alginolyticus, Vibrio metschinkovii, Vibrio mimicus, Vibrio damsela, and Vibrio fluvialis.

In a study conducted in India [38], found that $V$. alginolyticus (3-19\%), V. parahaemolyticus (2-13\%), V. harveyi (1-7\%), and $V$. vulnificus (1-4\%) were the predominant Vibrio species identified in water, sediment, and shrimp samples by standard biochemical testing. Koralage et al. [39] investigated the prevalence of Vibrio spp. in farmed shrimp (P. monodon) in Sri Lanka. Overall, $98.1 \%$ of the farms and $95.1 \%$ of the ponds were positive for Vibrio spp. In shrimp, at the pond level, V. parahaemolyticus $(91.2 \%)$ was the most common, followed by $V$. alginolyticus $(18.8 \%)$, $V$. cholerae non-O1/non-O139 (4.1\%), and V. vulnificus $(2.4 \%)$. Abd-Elghany and Sallam [40] verified by molecular PCR that 20/120 (16.7\%) of shellfish samples were positive for $V$. parahaemolyticus. The prevalence among shrimp collected from different fish shops in Mansoura city, Egypt, was 9 (22.5\%) of 40 examined samples [40].

A much higher prevalence $(55 \cdot 8 \%)$ was recorded in shrimp samples collected in the city of Agadir, Morocco [41], where $V$. parahaemolyticus was recovered from 25 of 299 samples $(8 \cdot 4 \%)$, V. cholerae from six samples (2\%), and $V$. alginolyticus from 161 samples $(53 \cdot 8 \%)$. Biju and Gunalan [30] revealed that the overall occurrence of Vibrio species from moribund shrimp samples from three major Indian shrimp farm villages was $29.01 \%$. Odeyemi [42] reported the incidence of $48.3 \%$ of $V$. parahaemolyticus in shrimps.

In contrast, in Croatia [43], the prevalence of $V$. parahaemolyticus in shellfish was $15 \%$. However, the examined crustaceans were negative. 
In India [35], Vibrio spp., Aeromonas spp., and Pseudomonas spp. were isolated from the hepatopancreas, hemolymph, intestine, gills, and eroded portion of the exoskeleton of cultured $P$. monodon. Luminous $V$. harveyi was the dominant bacterial flora in the affected organs, followed by non-luminous $V$. harveyi, $V$. parahaemolyticus, $V$. alginolyticus, other Vibrio spp., Aeromonas spp., and Pseudomonas spp.

With respect to $A$. hydrophila, Vivekanandhana et al. [44] analyzed 278 prawn samples from the major fish market of Coimbatore, South India. They recorded that the prevalence of $A$. hydrophila in Penaeus indicus, $P$. monodon, and $P$. semisulcatus was $16.58 \%, 13.20 \%$, and $25.52 \%$, respectively.

In the same line, Khamesipour et al. [45] examined 36 shrimp samples in Iran. Fourteen (38.9\%) $A$. hydrophila strains were confirmed by conventional bacteriological techniques, while five strains (13.89\%) were identified by PCR targeting $16 \mathrm{~S}$ rRNA gene.

In our study, we could identify $P$. shigelloides using duplex PCR and by sequencing. However, the reference study [25] did not mention that Plesiomonas could be amplified using their specified PCR protocol. $P$. shigelloides is included within the bacterial family Vibrionaceae which also contains the genus Vibrio. Both P. shigelloides and some Vibrio spp. are known causes of food poisoning in man [46]. Many cases of Plesiomonasassociated eye and wound infections have been documented $[46,47]$. P. shigelloides is present in freshwater ecosystems (rivers, lakes, and surface waters) and marine estuaries in tropical and temperate climates [48]. P. shigelloides, A. hydrophila, and Pseudomonas spp. strains had been isolated from sick guppy fishes (Poecilia reticulata) that belonged to aquarium fish rearing farms in Istanbul Province, Turkey [49]. The sick fish suffered from ascites, emaciation, and fin rot. P. shigelloides had also been isolated from the gut of wild and cultured banana prawns, Penaeus merguiensis [50].

The other spp. recovered on sequencing were Pseudomonas putida and P. fluorescens. Pseudomonas spp. are opportunistic human pathogens. They are prevalent in patients with skin infections who are considered as the main source of water contamination; they can also cause diarrhea and even septicemia [51-53]. They had also been reported in seafood $[20,54,55]$. Nevertheless, public health hazard arises to food consumers when their count exceeds $10^{6}-10^{7} \mathrm{cfu} / \mathrm{g}$ of product [56].

\section{Decontamination of shrimp using organic acids}

Consumers' protection against foodborne pathogens is a global public health issue. Certain organic acids have been used to limit microbial contamination and dissemination of foodborne pathogens in pre-harvest and post-harvest food production and processing, thus prolonging food shelf life and conserving food appealing to consumers [57]. The antibacterial activity of organic acids may vary depending on the physiological status of the organism and the physicochemical characteristics of their external environment [16].

In the current study, citric acid was found to be more effective in reducing $A$. hydrophila and $V$. parahaemolyticus counts than acetic acid at short marination period $(0.25$ and $1 \mathrm{~h})$ at both temperatures. After that, time acetic acid outperformed. Furthermore, citric acid was more effective at refrigerator temperature than citric acid at room temperature at the same time. To sum up, acetic acid showed an ascending increase in the reduction percentages to reach $100 \%$ reduction for Aeromonas after $24 \mathrm{~h}$ at both temperatures and $33.63 \%$ and $60 \%$ reduction for $V$. parahaemolyticus at refrigerator and room temperatures, respectively. The reduction effect using acetic acid was more effective at room temperature than that at refrigerator temperature for both microorganisms.

Our result is supported by Mathur's findings [28] that lime juice is effective in inactivation of both V. parahaemolyticus and Salmonella Enterica. He also found that refrigeration while marinating the fish had a significant impact on Salmonella reduction. A reduction $\sim 0.5 \log$ was observed in the first $10 \mathrm{~min}$ after application of lime juice on Salmonella in ceviche marinated at room temperature. The reductions remained almost constant until time $60 \mathrm{~min}$. An extended incubation for 150 min produced a $\log$ reduction of 1.3 . Log reductions in $V$. parahaemolyticus in experiments at room temperature varied from $>4.5$ to $>5.2$, while, at refrigerator temperature, log reductions varied from $>3.5$ to $>4.3$. When he tested the inhibitory effect of lime juice, without the fish matrix, he found more than $5 \log$ reductions in counts on both bacteria.

Our observation that lemon juice was more effective at refrigerator temperature than lemon at room temperature at 0.25 and $1 \mathrm{~h}$ is supported by Mathur's postulation [28] that when cells are exposed concurrently to two stresses (acid and refrigeration), this results in a greater reduction.

Furthermore, Mata et al. [58] studied the effect of lime juice on $V$. cholerae $\mathrm{O} 1$ on commercially prepared ceviche (from mahi-mahi fish), ceviche prepared from the fish contaminated in the laboratory and also by adding the bacteria directly to lime juice without the fish matrix. Their results were as follows: For commercial ceviche, no bacteria were recovered after 15-30 min of exposure, while a $4 \log$ reduction in ceviche prepared in a laboratory was observed after $30 \mathrm{~min}$. For addition of Vibrio directly to the lime juice, a $3 \log$ reduction within $5 \mathrm{~min}$ and complete elimination after $2 \mathrm{~h}$ were observed. The buffering effect of shrimp or fish tissues was thought as a reason for reducing the antimicrobial effect of acidic sauces [28,58].

In the experiment performed by Rodrigues et al. [59], limes were shown to limit foodborne transmission of Vibrio cholera. In the same line, Tomotake et al. [60] found that lime fruit juices were effective against Vibrio species. 
Lime juice contains essential oils, saponins, and flavonoid compounds which have an antibacterial and bacteriostatic character. These compounds inhibit metabolism and growth of bacteria $[61,62]$. The citrus peels contain essential oils (rich in phenolic compounds) which are responsible for the antimicrobial activity of squeezed citrus fruits [63].

Our finding that acetic acid outperformed citric acid was supported by Bang and Drake [64] who recorded a reduction of $6 \log$ of Vibrio vulnificus counts within $15 \mathrm{~min}$ at $\mathrm{pH} 3.5$ with citric acid. At $\mathrm{pH} 3.5$, acetic acid was more effective than citric acid. A concentration of $0.5 \%$ acetic acid was recommended for marinating seafood [57]. Furthermore, the concentrations of $0.07 \%$ acetic acid and above completely inhibited $V$. harveyi growth [65].

Accordingly, vinegar is esteemed as a natural antimicrobial product which can improve the shelf life and safety of food products, providing acceptable organoleptic quality at a fair price and reducing economic loss due to spoilage of food products.

The emerging challenging problem is that organic acids have been observed to induce an acid tolerance response (ATR) which enhances the survivability of acid-sensitive pathogens exposed to low $\mathrm{pH}$ and this is probably linked to increased virulence. The finding that Vibrio was more resistant to acid treatment is supported by previous researches $[64,66,67]$ which stated that all Vibrio spp. were found to be susceptible to low $\mathrm{pH}$ but gradually developed an ATR pattern if the stress was regulated. Adaptation to one stress also seems to provoke other physiological adaptations, resulting in adaptability to multiple stresses. In a study by Wong et al. [68] on V. parahaemolyticus, the acid adapted cells showed greater survival at low salinity and after thermal inactivation. In like manner, acid adaptation of $V$. parahaemolyticus with an accumulation of the decarboxylation product of lysine was reported [69]. Lysine decarboxylation is the mechanism thought to be related to acid tolerance response.

Furthermore, the fact that $V$. parahaemolyticus has a short generation time, it only takes 9 min in culture medium and $12 \mathrm{~min}$ in a host to produce one generation [70] may account for its smaller reduction percentages.

Due to the antibacterial effect of organic acids, they have been applied to animal and human nutrition. Feeds treated with organic acids are believed to limit pathogen colonization by conversion of these acids into their respective antibacterial forms once they have entered the digestive tract of humans, animals, fish, and shrimps consuming the treated feed [17,65,71-74].

\section{Conclusion}

Bacterial shrimp diseases as vibriosis and Aeromonas infections affect its health. The presence of Vibrio, Aeromonas, and other potential human pathogens in shrimp samples raises public health concern. Hence, hygienic measures should be practiced during handling and cooking of seafood. Organic acid treatment showed that vinegar and lemon juice could be used as a safe and economic method to limit the microbial contamination in seafood and to decrease the seafood borne-associated illness.

\section{Authors' Contributions}

HMF was responsible for the collection of samples, statistical analysis, designing, carrying out of the experiments, writing, and revising of the manuscript. MEMM shared in the collection of samples, statistical analysis, performance of the experiments, writing, and revising of the manuscript. Both authors read and approved the final manuscript.

\section{Acknowledgments}

The research was done at the Laboratory of Zoonoses, Faculty of Veterinary Medicine, Suez Canal University, Ismailia, Egypt. The research was funded by the authors.

\section{Competing Interests}

The authors declare that they have no competing interests.

\section{Publisher's Note}

Veterinary World (Publisher of International Journal of One Health) remains neutral with regard to jurisdictional claims in published map and institutional affiliation.

\section{References}

1. Dayal JS, Ponniah AG, Khan HI, Babu EP, Ambasankar K, Vasagam KP. Shrimps-a nutritional perspective. Curr Sci 2013;104:1487-91.

2. Center for Disease Control and Prevention (CDC a). The Final Update on a Multistate Outbreak of Vibrio parahaemolyticus Infections Linked to Fresh Crab Meat; 2018. Available from: https://www.cdc.gov/media/releases/2018/ s0927-vibrio-crab.html. [Last accessed on 2018 Oct 24].

3. Gopinath R. Extracellular Products of Aeromonas hydrophila and its Effects on Indian White Prawn, Penaeus indicus. M.Sc Thesis of Fisheries Science (Mariculture). Central Institute of Fisheries Education, (Deemed University); 1999.

4. Brock JA, Lightner DV. Diseases of Crustacea. In: Kinne O, editor. Diseases of Marine Animals. Vol. 3. Ch. 3. Hamburg: Biologische Anstalt Helgoland; 1990. p. 245-424.

5. Alavandi SV, Vijayank K, Rajendran KV. Shrimp diseases, their prevention and control. Ciba Bull 1995;3:1-17.

6. Teng T, Liang L, Chen K, Xi B, Xie J, Xu P, et al. Isolation, identification and phenotypic and molecular characterization of pathogenic Vibrio vulnificus isolated from Litopenaeus vannamei. PLoS One 2017;12:e0186135.

7. Center for Disease Control and Prevention (CDC b). Vibrio Species Causing Vibriosis; 2018. Available from: https:/www.cdc.gov/vibrio/faq.htm. [Last accessed on 2018 Oct 24].

8. Public Health of England (PHE). UK Standards for Microbiology, Investigations ID 19: Identification of Vibrio and Aeromonas species; 2015. Available from: https://www.gov.uk/government/publications/ 
smi-id-19-identification-of-vibrio-species. [Last accessed on 2018 Jan 24].

9. Lightner DV. A Handbook of Shrimp Pathology and Diagnostic Procedures for Diseases of Cultured Penaeid Shrimp. Baton Rouge, La, USA: World Aquaculture Society; 1996.

10. Harris LJ, Owens L. Production of exotoxins by two luminous Vibrio harveyi strains known to be primary pathogens of Penaeus monodon larvae. Dis Aquat Org 1999;8:11-22.

11. Zaki VH, Abdelkhalek NK, Shakweer MS. Environmental conditions/bacterial infections relationship and their impact on immune parameters of cultured Fenneropenaeus indicus with special reference to in-vitro antibiotic susceptibility. Int J Fish Aquat Stud 2016;4:51-8.

12. Li P, Kinch LN, Ray A, Dalia AB, Cong Q, Nunan LM, et al. Acute hepatopancreatic necrosis disease-causing Vibrio parahaemolyticus strains maintain an antibacterial Type VI secretion system with versatile effector repertoires. Appl Environ Microbiol 2017;83:1-17.

13. Selvin J, Ninawe AS, Meenatchi R, Kiran GS. Control of Pathogenic Vibrios in Shrimp Aquaculture using Antiinfectives from Marine Natural Products. México, Nuevo León: Conference: Nutrición Acuícola: Investigación y Desarrollo, Universidad Autónoma de Nuevo León, San Nicolás de los Garza; 2015. p.102-41.

14. Batra P, Mathur P, Misra MC. Aeromonas spp.: An emerging nosocomial pathogen. J Lab Physicians 2016;8:1-4.

15. FDA. Electronic Code of Federal Regulations (ECFR). Part 184-Direct Food Substances Affirmed as Generally Recognized as Safe; 2018. Available from: https://www. fda.gov/food/ingredients packaging labeling/GRAS/. [Last accessed on 2018 Nov 24].

16. Ricke SC. Perspectives on the use of organic acids and short chain fatty acids as antimicrobials. Poult Sci 2003;82:632-9.

17. Vinus NS, Tewatia BS. Organic acids as alternatives to antibiotic growth promoters in poultry. Pharm Innov 2017;6:164-9.

18. Animal Research Regulation; 2010. Available from: https:// www.legislation.nsw.gov.au/\#/view/regulation/2010/425. [Last accessed on 2019 Apr 12].

19. Noga EJ. Fish Disease Diagnosis and Treatment. $2^{\text {nd }}$ ed. USA Mosby-Yearbook, Inc. Watsworth Publishing Co.; 2010.

20. Yagoub SO. Isolation of Enterobacteriaceae and Pseudomonas spp. From raw fish sold in fish market in Khartoum state. J Bacteriol Res 2009;1:85-8.

21. Martin-Carnahan A, Joseph SW. Genus I. Aeromonas stanier 1943, 213al. In: Brenner DJ, Krieg NR, Staley JT, Garrity GM, editors. Bergey's Manual of Systematic Bacteriology. $2^{\text {nd }}$ ed., Vol. 2. Part B. New York: Springer; 2005. p. 557-78.

22. Janda JM, Abbott SL. The genus Aeromonas: Taxonomy, pathogenicity, and infection. Clin Microbiol Rev 2010;23:35-73.

23. Farmer $\mathrm{JJ} 3^{\text {rd }}$, Janda JM, Brenner FW, Cameron DN, Birkhead KM. Genus I. Vibrio Pacini 1854, 411al. In: Brenner DJ, Krieg NR, Staley JT, Garrity GM, editors. Bergey's Manual of Systematic Bacteriology. $2^{\text {nd }}$ ed., Vol. 2. Part B. New York: Springer; 2005. p. 494-546.

24. Soumet C, Ermel G, Fach P, Colin P. Evaluation of different DNA extraction procedures for the detection of Salmonella from chicken products by polymerase chain reaction. Lett Appl Microbiol 1994;19:294-8.

25. Mendes-Marques CL, Hofer E, Leal NC. Development of duplex-PCR for identification of Aeromonas species. Rev Soc Bras Med Trop 2013;46:355-7.

26. Weisburg WG, Barns SM, Pelletier DA, Lane DJ. 16S ribosomal DNA amplification for phylogenetic study. J Bacteriol 1991;173:697-703.

27. Shirazinejad A, Ismail N, Bhat R. Lactic acid as a potential decontaminant of selected foodborne pathogenic bacteria in shrimp (Penaeus merguiensis de man). Foodborne Pathog
Dis 2010;7:1531-5.

28. Mathur P. The Effect of Lime Juice on Vibrio parahaemolyticus and Salmonella Enterica Inactivation during the Preparation of Raw Fish Dish Ceviche. MSc. Thesis, Graduate School-New Brunswick Rutgers, The State University of New Jersey; 2012.

29. George Brown College Tutoring and Learning Centre. Percentage Change; 2014. Available from: http://www. georgebrown.ca/uploadedFiles/TLC/ documents/ Percentage\%20Change.pdf. [Last accessed on 2017 Aug 20].

30. Biju VN, Gunalan B. Prevalence of Vibrio infection in Penaeus (litopenaeus) vannamei farms. Int J Sci Invent Today 2016;5:485-93.

31. Cheng AC, Shiu YL, Chenn BJ, Huynh TJ, Liu CH. Isolation and identification of pathogenic bacterium Aeromonas veronii from ornamental shrimp Caridina $c f$. babaulti. J Fish Soc Taiwan 2016;43:273-83.

32. Taylor HH, Taylor EW. Gills and lungs: The Exchange of Gases and Ions. In: Harrison FW, Humes AG, editors. Microscopic Anatomy of Invertebrates 10. New York: Wiley-Liss; 1992. p. 203-93.

33. Ali MN, Abo-Esa JF. Study on some causative agents' infection in Red Sea shrimp (Penaeus semiculcatus) in summer season. Egypt J Aquat Biol Fish 2007;11:645-56.

34. El-Bouhy ZM, Abdelrazek FA, Hassanin ME. A contribution on vibriosis in shrimp culture in Egypt. Egypt J Aquat Res 2006;32:443-56.

35. Abraham TJ, Sasmal D, Dash G, Nagesh TS, Das SK, Mukhopadhayay SK, et al. Epizootology and pathology of bacterial infections in cultured shrimp Penaeus monodon Fabricius 1798 in West Bengal, India. Indian J Fish 2013;60:167-71.

36. Aly SM, El-Attar AA. Pathological studies on some bacterial pathogens of cultured shrimp. Assiut Vet Med J 2001;45:298-331.

37. El-Hadi N, Radu S, Chen CH, Nishibuchi M. Prevalence of potentially pathogenic Vibrio species in the seafood marketed in Malaysia. J Food Prot 2004;67:1469-75.

38. Gopal S, Otta SK, Kumar S, Karunasagar I, Nishibuchi M, Karunasagar I, et al. The occurrence of Vibrio species in tropical shrimp culture environments; implications for food safety. Int J Food Microbiol 2005;102:151-9.

39. Koralage MS, Alter T, Pichpol D, Strauch E, Zessin KH, Huehn S. Prevalence and molecular characteristics of Vibrio spp. isolated from preharvest shrimp of the North Western Province of Sri Lanka. J Food Prot 2012;75:1846-50.

40. Abd-Elghany SM, Sallam KI. Occurrence and molecular identification of Vibrio parahaemolyticus in retail shellfish in Mansoura, Egypt. Food Control 2013;33:399-405.

41. Kriem MR, Banni B, El Bouchtaoui H, Hamama A, El Marrakchi A, Chaouqy N, et al. Prevalence of Vibrio spp. in raw shrimps (Parapenaeus longirostris) and performance of a chromogenic medium for the isolation of Vibrio strains. Lett Appl Microbiol 2015;61:224-30.

42. Odeyemi OA. Incidence and prevalence of Vibrio parahaemolyticus in seafood: A systematic review and meta-analysis. Springerplus 2016;5:464.

43. Popovic NT, Skukan AB, Dzidara P, Coz-Rakovac R, Strunjak-Perovic I, Kozacinski L, et al. Microbiological quality of marketed fresh and frozen seafood caught off the Adriatic coast of Croatia. Vet Med 2010;55:233-41.

44. Vivekanandhana G, Hatha AA, Lakshmanaperumalsamy P. Prevalence of Aeromonas hydrophila in fish and prawns from the seafood market of Coimbatore, South India. Food Microbiol 2005;22:133-7.

45. Khamesipour F, Moradi M, Noshadi E, Shahraki MM. Detection of the prevalence of Aeromonas hydrophila in shrimp samples by polymerase chain reaction $(\mathrm{PCR})$ and cultural method in Iran. J Biol Environ Sci 2014;4:47-52.

46. Janda JM, Abbott SL, McIver CJ. Plesiomonas shigelloides 
revisited. Clin Microbiol Rev 2016;29:349-74.

47. Klatte JM, Daswtjerdi MH, Clark K, Harrison CJ, Grigorian F, Stahl ED. Hyper acute infectious keratitis with Plesiomonas shigelloides following traumatic lamellar corneal laceration. Pediatr Infect Dis J 2012;31:1200-1.

48. Levin RE. Plesiomonas shigelloides-An aquatic foodborne pathogen: A review of its characteristics, pathogenicity, ecology, and molecular detection. Food Biotechnol 2008;22:189-202.

49. Akaylı T, Zeybek Z. Bazı akvaryum baliklarinda Plesiomonas shigelloides enfeksiyonu üzerinde bir araştirma. E.U. J Fish Aquat Sci 2005;22:31-4.

50. Oxley AP, Shipton W, Owens L, McKay D. Bacterial flora from the gut of the wild and cultured banana prawn, Penaeus merguiensis. J Appl Microbiol 2002;93:214-23.

51. Yoshino Y, Kitazawa T, Kamimura M, Tatsuno K, Ota Y, Yotsuyanagi H. Pseudomonas putida bacteremia in adult patients: Five case reports and a review of the literature. J Infect Chemother 2011;17:278-82.

52. Akram F, Pietroni MA, Bardhan PK, Bibi S, Chisti MJ. Prevalence, clinical features, and outcome of Pseudomonas bacteremia in under-five diarrheal children in Bangladesh. ISRN Microbiol 2014;2014:469758.

53. Hashish NM, Abbass AA, Amine AE, Kanan S, Pseudomonas aeruginosa in swimming pools. Cogent Environ Sci 2017;3:1328841.

54. Adebayo-Tayo BC, Odu NN, Igiwiloh NJ, Okonko IO. Microbiological and physicochemical level of fresh catfish (Arius hendelotic) from different markets in Akwa Ibom state, Nigeria. N Y Sci J 2012;5:46-52.

55. Ardura A, Linde AR, Garcia-Vazquez E. Genetic detection of Pseudomonas spp. in commercial Amazonian fish. Int J Environ Res Public Health 2013;10:3954-66.

56. Craun GF, Brunkard JM, Yoder JS, Roberts VA, Carpenter J, Wade T, et al. Causes of outbreaks associated with drinking water in the United States from 1971 to 2006. Clin Microbiol Rev 2010;23:507-28.

57. Lingham T, Besong S, Ozbay G, Lee JL. Antimicrobial activity of vinegar on bacterial species isolated from retail and local channel catfish (Ictalurus punctatus). J Food Process Technol 2012;S11:1.

58. Mata L, Vives M, Vicente G. Extinction of Vibrio cholerae in acidic substrata: Contaminated fish marinated with lime juice (ceviche). Rev Biol Trop 1994;42:479-85.

59. Rodrigues A, Sandström A, Cá T, Steinsland H, Jensen H, Aaby $\mathrm{P}$, et al. Protection from cholera by adding lime juice to food-results from community and laboratory studies in Guinea-Bissau, West Africa. Trop Med Int Health 2000;5:418-22.
60. Tomotake H, Koga T, Yamato M, Kassu A, Ota F. Antibacterial activity of citrus fruit juices against Vibrio species. J Nutr Sci Vitaminol (Tokyo) 2006;52:157-60.

61. Cowan MM. Plant products as antimicrobial agents. Clin Microbiol Rev 1999;12:564-82.

62. Suradi K, Wulandari E, Permatasari I. The effect of concentrations of lime juice (Citrus aurantifolia) toward acceptability and storage life of culled layer hens meat. Sci Pap Ser D Anim Sci 2015;58:339-41.

63. Priyadarshini S, John S, Iyer P. Antimicrobial activity and characterization of microflora of vinegar preparations developed from peels and fruit of sweet lime. Eur J Biotechnol Biosci 2014;2:42-5.

64. Bang W, Drake MA. Acid adaptation of Vibrio vulnificus and subsequent impact on stress tolerance. Food Microbiol 2005;22:301-9.

65. Mine S, Boopathy R. Effect of organic acids on shrimp pathogen, Vibrio harveyi. Curr Microbiol 2011;63:1-7.

66. Koo J, DePaola A, Marshall DL. Impact of acid on survival of Vibrio vulnificus and Vibrio vulnificus phage. J Food Prot 2000;63:1049-52.

67. Merrell DS, Bailey C, Kaper JB, Camilli A. The toxR-mediated organic acid tolerance response of Vibrio cholerae requires ompU. J Bacteriol 2001;183:2746-54.

68. Wong HC, Peng PY, Han JM, Chang CY, Lan SL. Effect of mild acid treatment on the survival, enteropathogenicity, and protein production in Vibrio parahaemolyticus. Infect Immun 1998;66:3066-71.

69. Yeung SM, Boor KJ. Effects of acid stress on Vibrio parahaemolyticus survival and cytotoxicity. J Food Prot 2004;67:1328-34.

70. Oliver JD, Pruzzo C, Vezzulli L, Kaper JB. Vibrio species. In: Doyle MP, Buchanan RL, editors. Food Microbiology: Fundamentals and Frontiers. $4^{\text {th }}$ ed. Washington, DC: ASM Press; 2013. p. 401-39.

71. Koo J, Marshall DL, DePaola A. Antiacid increases survival of Vibrio vulnificus and Vibrio vulnificus phage in a gastrointestinal model. Appl Environ Microbiol 2001;67: 2895-902.

72. Khan SH, Iqbal J. Recent advances in the role of organic acids in poultry nutrition. J Appl Anim Res 2016;44:359-69.

73. Dittoe DK, Ricke SC, Kiess AS. Organic acids and potential for modifying the avian gastrointestinal tract and reducing pathogens and disease. Front Vet Sci 2018;5:216.

74. Rimoldi S, Gliozheni E, Ascione C, Gini E, Terova G. Effect of a specific composition of short- and medium-chain fatty acid 1-Monoglycerides on growth performances and gut microbiota of gilthead sea bream (Sparus aurata). Peer J 2018;6:e5355.

\section{$* * * * * * * *$}

